Article

\title{
The Relationship between Air-Mass Trajectories and the Abundance of Dust-Borne Prokaryotes at the SE Mediterranean Sea
}

\author{
Eyal Rahav ${ }^{1, *}$, Natalia Belkin ${ }^{1}$, Adina Paytan ${ }^{2}$ and Barak Herut ${ }^{1}$ (1) \\ 1 Israel Oceanographic and Limnological Research, National Institute of Oceanography, Haifa 8030, Israel; \\ belkin@ocean.org.il (N.B.); barak@ocean.org.il (B.H.) \\ 2 Institute of Marine Science, University of California, Santa Cruz, CA 95064, USA; apaytan@ucsc.edu \\ * Correspondence: eyal.rahav@ocean.org.il
}

Received: 1 May 2019; Accepted: 18 May 2019; Published: 20 May 2019

\begin{abstract}
Airborne prokaryotes are transported along with dust/aerosols, yet very little attention is given to their temporal variability above the oceans and the factors that govern their abundance. We analyzed the abundance of autotrophic (cyanobacteria) and heterotopic airborne microbes in 34 sampling events between 2015-2018 at a coastal site in the SE Mediterranean Sea. We show that airborne autotrophic $\left(0.2-7.6\right.$ cells $\left.\times 10^{3} \mathrm{~m}^{-3}\right)$ and heterotrophic $\left(0.2-30.6\right.$ cells $\left.\times 10^{3} \mathrm{~m}^{-3}\right)$ abundances were affected by the origin and air mass trajectory, and the concentration of dust/aerosols in the air, while seasonality was not coherent. The averaged ratio between heterotrophic and autotrophic prokaryotes in marine-dominated trajectories was $\sim 1.7 \pm 0.6$, significantly lower than for terrestrial routes $(6.8 \pm 6.1)$. Airborne prokaryotic abundances were linearly and positively correlated to the concentrations of total aerosol, while negatively correlated with the aerosol's anthropogenic fraction (using $\mathrm{Pb} / \mathrm{Al}$ or $\mathrm{Cu} / \mathrm{Al}$ ratios as proxies). While aerosols may play a major role in dispersing terrestrial and marine airborne microbes in the SE Mediterranean Sea, the mechanisms involved in the dispersal and diversity of airborne microorganisms remain to be studied and should include standardization in collection and analysis protocols.
\end{abstract}

Keywords: airborne bacteria; airborne cyanobacteria; dust deposition; Southeastern Mediterranean Sea

\section{Introduction}

The atmosphere is a major transport vector for aerosols, including mineral dust and anthropogenic constituents, which supply nutrients to the surface ocean (e.g., N, P, Fe), thus fueling microbial activity, biomass and growth [1-3]. Airborne microbes are also transported along with the dust/aerosols [4-6] and may therefore play a pivotal role in the biochemistry of the receiving environment (oceans, lakes or land). Airborne microbes can contribute to bacterial production, $\mathrm{N}_{2}$ fixation and viral infections [7-10] and affect diverse atmospheric processes (e.g., formation of clouds and snow, [11]). Currently, estimates of airborne prokaryotic microorganisms (bacteria and archaea) over large water bodies such as the ocean and lakes are limited, despite the vast coverage of these water bodies on Earth's surface [12]. A recent study covering the tropical and subtropical ocean in the Atlantic, Pacific and Indian basins showed that airborne bacteria are highly abundant $\left(\sim 10^{21}\right.$ cells $)$ and originate from both marine and terrestrial environments [12]. Airborne prokaryotic diversity may depend on the dust/aerosol's origin and route prior to deposition $[9,13,14]$, while their viability may depend on other factors such as damaging levels of UV radiation, desiccation, the atmospheric temperature amplitudes, and atmospheric acidity [15]. Nevertheless, up to $\sim 20 \%$ of all airborne prokaryotes remain viable during atmospheric transport [16]. Further, since airborne prokaryotic cells are mostly attached to soil 
particles [17], they may have an advantage accessing nutrients associated with aerosol, and therefore their cell-specific growth rate following deposition may be higher than that of ambient microbial populations $[9,18]$.

In this study, we estimated the temporal variability of heterotrophic and autotrophic airborne prokaryotic microbes off the SE Mediterranean coast for 3 years (2015-2018). Our data show that airborne microbes were abundant throughout the year and that their metabolic carbon acquisition mechanism (i.e., autotrophic or heterotrophic microbe) varied based on their place of origin (marine or terrestrial source/air-mass back trajectories).

\section{Material and Methods}

Dust/aerosol collection-Air particles were collected from the SE Mediterranean coast onto 4 Supor sterile $47 \mathrm{~mm}$ polycarbonate filters (PALL, Product ID: 66234) using a custom-made total suspended particle sampler located on the rooftop of the Israel Oceanographic and Limnological research (IOLR) institute, $\sim 20 \mathrm{~m}$ above sea level. The sampler's air pump was set to $40 \mathrm{~m}^{3} \mathrm{~h}^{-1}$ and samples collection ranged between 7-63 h (Figure 1). Thirty-four samples were collected in total between 2015-2018 and were analyzed for autotrophic and heterotrophic prokaryotic (bacteria and archaea) abundance and for bulk concentration (total digestion) of select trace metals $(\mathrm{Al}, \mathrm{Pb}$, and $\mathrm{Cu}$ ). Concurrent air mass back trajectories arriving at $10 \mathrm{~m}$ altitude were also computed using the HYSPLIT model [19] and compared to the prokaryotes reads. Additional air-mass backward trajectory simulations arriving at 100, 250, and $500 \mathrm{~m}$ altitudes were also run and compared to the $10 \mathrm{~m}$ maps, with no significant differences (not shown). The GDAS 0.5-degree meteorology data was used to run the backward trajectories using a vertical velocity motion. Aerosol/dust origin was then classified to either terrestrial or marine origin based on the time (hours) the particles (and air masses) spent over the different media.
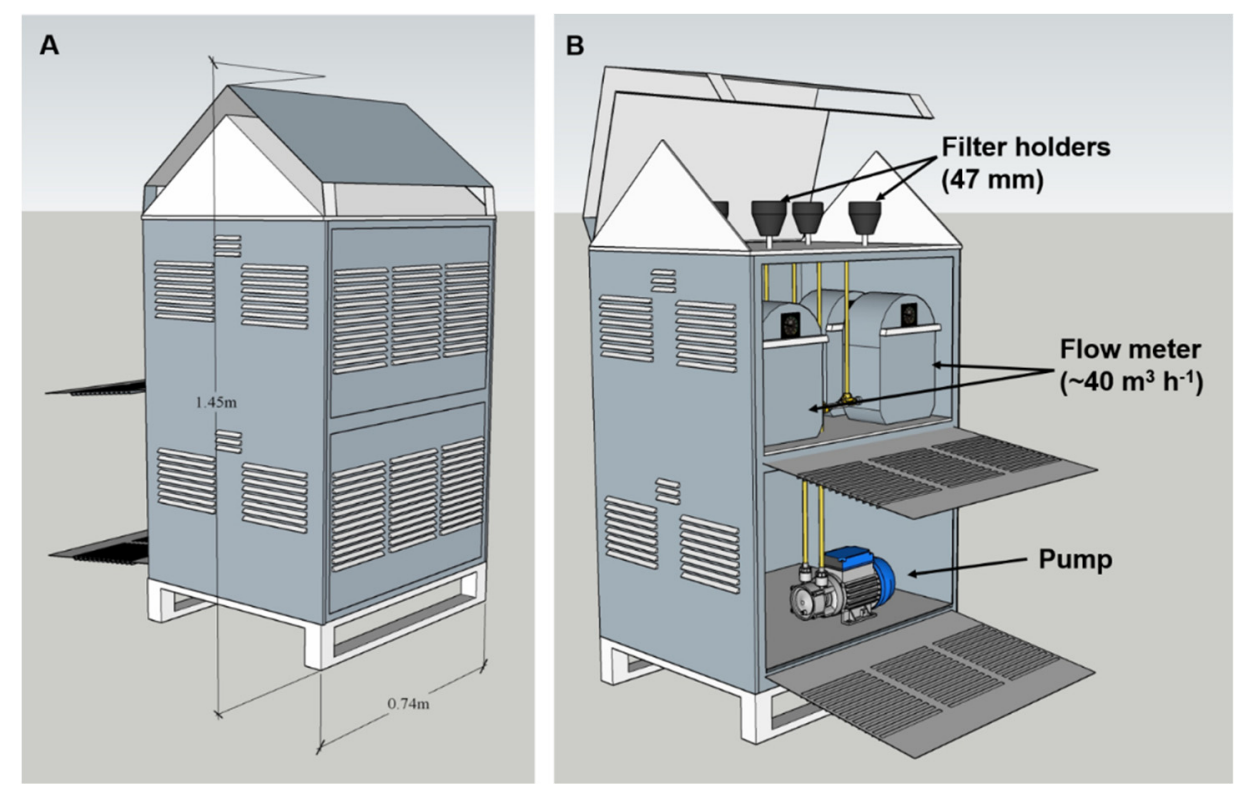

Figure 1. A schematic illustration of the custom-made air volume sampler used to collect dust and corresponding airborne microbes on the rooftop of the IOLR ( 20 m above sea level) between 2015-2018. Dust/aerosol particles in the air were vacuum pumped at $\sim 40 \mathrm{~m}^{3} \mathrm{~h}^{-1}$ for $7-63 \mathrm{~h}$ onto sterile $47 \mathrm{~mm}$ polycarbonate filters.

Trace metals concentration-Suspended particles were collected in parallel to airborne microbes (Figure 1 ) on acid-clean $(\mathrm{HCl}, 10 \%)$ and pre-weighted Whatman 41 filters using a second high-volume sampler as described in Herut et al. (2001). After collection, the Whatman 41 filters were dried in a desiccator for $24 \mathrm{~h}$ before being reweighed. Trace metals $(\mathrm{Al}, \mathrm{Cu}$, and $\mathrm{Pb}$ ) were measured after total digestion with hydrogen fluoride (HF) following the procedure of ASTM (1983) as described in Herut 
et al [20]. The concentrations were measured on an atomic absorption spectrometer Agilent 280FS AA and graphite furnace Agilent 240Z AA. Dry deposition rates were calculated based on total Al concentration of the collected aerosol, a settling velocity of $1.8 \mathrm{~cm} \mathrm{~s}^{-1}$ [21], and the particles' weights collected on the filter for the volume pumped during the collection time.

Airborne prokaryotes abundance-Collected material from filters was re-suspended in $3 \mathrm{~mL}$ of filtered seawater $(0.2 \mu \mathrm{m})$ from the study site and sonicated (Symphony) for $1 \mathrm{~min}$. The filtered seawater was then preserved with microscopy-grade glutaraldehyde solution (Sigma-Aldrich G7651, final concentration $0.2 \%$ ) and frozen in liquid nitrogen before being transferred to $-80{ }^{\circ} \mathrm{C}$. Before analyses, samples were defrosted in a $37^{\circ} \mathrm{C}$ water bath, well mixed for $30 \mathrm{~s}$, and $100 \mu \mathrm{L}$ aliquot was stained with SYTO9 (1:10 v:v) for $10 \mathrm{~min}$ in the dark. Cell counts in the samples were determined using an Attune $囚$ Acoustic Focusing Flow Cytometer (Applied Biosystems) equipped with 488 and 405 -nm lasers at $25 \mu \mathrm{L} \mathrm{min}^{-1}$ using a discrimination threshold of green fluorescence and forward-scatter. Cyanobacterial abundance was determined on non-stained samples at $100 \mu \mathrm{L} \mathrm{min}^{-1}$ with taxonomic discrimination set on the orange and red fluorescence, on side-scatter and on forward-scatter [22,23]. Beads $(0.93 \mu \mathrm{m}$, Polysciences) were used as a size standard. Three filters in each event (out of total 4 collected) were used for bacterial abundance measurements and 1 filter served as a negative control where no air was pumped through it. Further, the reads retrieved from the filtered seawater $(<10 \%$ of total events) were also used as a negative control and were subtracted from the total cell reads.

Statistical analyses-All statistical analyses were performed using the XLSTAT software (a Microsoft Excel add-in product). Pearson regression correlation analyses were carried out at $p$-value $<0.05$. A Shapiro-Wilk normality test (Gaussian distribution) was conducted to make sure the data is normally distributed before running the parametric test. The differences in airborne microbes between sites/studies were evaluated using a one-way analysis of variance (ANOVA), followed by a Fisher Least Significant Difference (LSD) multiple comparison post-hoc test with a confidence level of $95 \%(\alpha=0.05)$.

\section{Results and Discussion}

Mean daily dust deposition to the Southeastern Mediterranean Sea waters ranged from $\sim 0.01-0.2 \mathrm{~g} \mathrm{~m}^{-2}$ based on $\mathrm{Al}$ concentration and using an average $\mathrm{Al}$ to total mineral dust of $7 \%$, and a settling velocity of $1.8 \mathrm{~cm} \mathrm{~s}^{-1}$ [21]. These values concur with previous studies showing that areas close to desert sources, such as the SE Mediterranean, receive 1-50 g dust $\mathrm{m}^{-2}$ year $^{-1}[2,24]$. Three-day backward trajectories were calculated for each sample with transects arriving at $10 \mathrm{~m}$ (Figure 2). These trajectories show varying origin locations, routes, distances, altitudes, and distributed to the following sectors: Europe (Northwest, 39\% of all events), the Sahara Desert (Southwest, $37 \%$ ), the Arabian Peninsula (Southeast, 12\%) and Iraq/Syria (Northeast, 12\%). In 16 events (47\% of all events investigated in this study) a marine air-mass route was observed prior dust/aerosol collection, whereas in the other 18 events (53\%) the trajectories exhibited a terrestrial route. Previous studies showed that the dust/aerosol's atmospheric route has a significant effect on the number of prokaryotic microorganisms in the sample [9], as well as on the microbial diversity of the aerosol particle source $[9,14,25,26]$. Furthermore, the atmospheric route and conditions during transport (humidity, cloud cover, acidity) may affect the in-situ responses triggered in the surface oceans post-deposition. For example, addition of polluted aerosol particles resulted in a larger/stronger "biological" response than with Saharan dust particles in a mesocosm experiment at the Eastern Mediterranean waters $[3,27,28]$, likely due to the higher solubility of macro and micronutrients of this source [29]. Thus, trajectories are an important factor to consider when assessing the transport and biogeography of airborne microbes [25], as well as the corresponding activity/functions (viability, metabolic functions, etc.) of the associated microbial community $[7,9,10,30,31]$. 

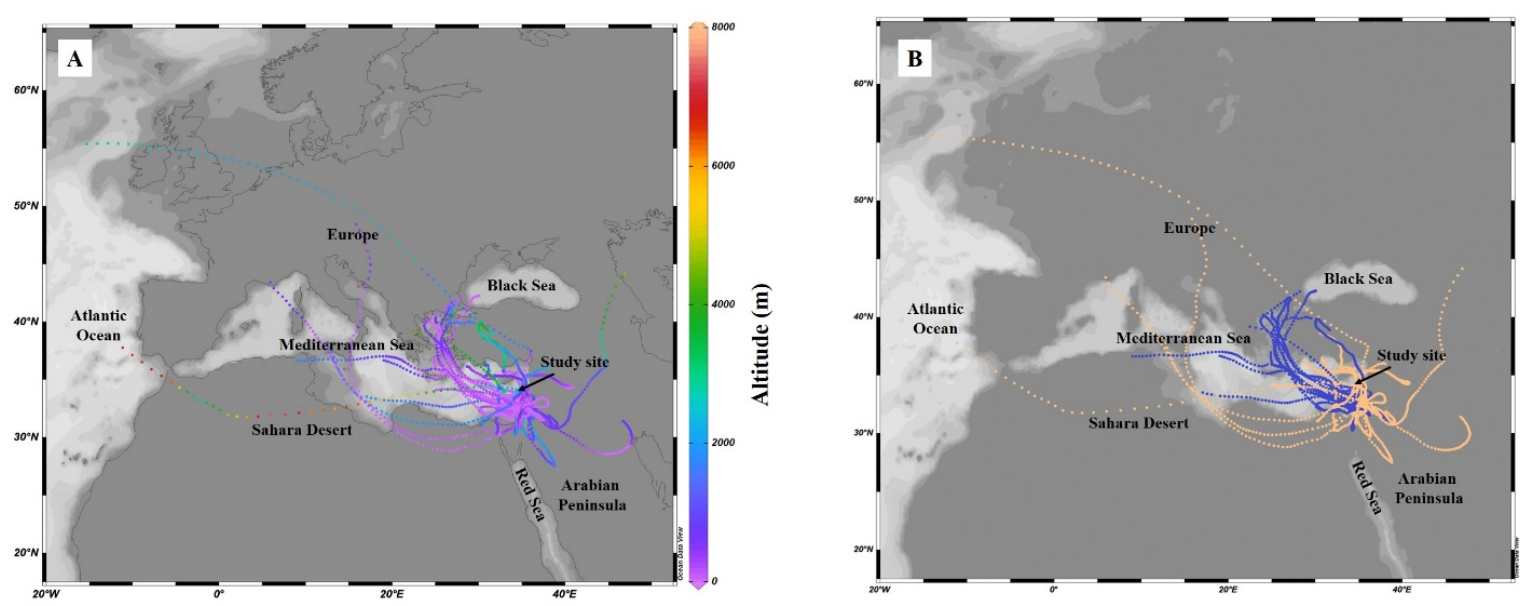

Figure 2. (A) Backward trajectories calculated with NOAA HYSPLIT model arriving at $10 \mathrm{~m}$ altitude to Tel-Shikmona, Haifa (SE Mediterranean coast) between 2015-2018 $(n=34)$. (B) A summary of the main trajectories computed/calcified based on the route prior collection; marine (blue) and terrestrial (brown).

Our measurements show that heterotrophic and autotrophic (cyanobacteria) airborne prokaryotes were abundant throughout the study period (2015-2018, Figure 3). Heterotrophic prokaryotic microorganisms ranged from 188-30,601 cells $\mathrm{m}^{-3}$ air (Figure 3A), in accordance with measurements taken throughout the Atlantic [12,32], Pacific and Indian oceans [12], and the Sea of Japan [33], yet lower by an order of magnitude than recently reported in the central Red Sea [34] (Figure 4). The variability in the prokaryotic cell abundances may be attributed to the distance from nearby shore/land [12], the atmospheric route (i.e., height, duration), the concentration of dust/aerosol, as well as to differences in methodology of aerosol collection and procedure for assessing cell numbers (i.e., microscopy, qPCR, culture-based methods) $[12,33,35]$. Further, different meteorological conditions such as wind speed, humidity, and atmospheric $\mathrm{pH}$ may also affect airborne microbial community structure [36,37].

Airborne cyanobacterial abundance was usually lower than the abundance of heterotrophic microbes ( $t$-test, $p<0.01$ ), and ranged from $163-7575$ cells m$^{-3}$ (Figure 3A), as has been reported from pollen traps in Southwest Spain [38]. The occasional peaks in airborne microbial abundances were linearly correlated to the concentration of dust (as estimated using Al) (Figure 3C, Pearson correlation, $p<0.05$ ), while seasonal variations in airborne microorganism's abundance were not statistically significant (ANOVA, $p=0.27$, Figure 3A). This is opposing to some previous studies showing that air temperature may affect airborne bacterial community composition [39-41]. However, monitoring of airborne bacteria in the Sea of Japan also showed a 10-fold higher abundance associated with severe Asian dust events than in "typical" (non-dusty) days, while seasonal variations were not observed [33]. The higher microbial abundance associated with mineral dust content may be attributed to the shielding and protection of microbes associated with soil particles from UV radiation in the atmosphere and the higher humidity around the particles due to water adsorption [17,42]. The lack of apparent seasonality and the positive correlation between dust/aerosols concentrations and airborne microbial abundance highlight the "episodic nature" of intense dust/aerosol events that inject airborne microbes into the surface oceans. Such episodic "pulses" can transport indigenous microbial communities such as Methylobacterium, Pseudomonas, and Enterobacteriales downwind of the sources areas, as described for the Gobi Desert region [33]. These data suggest that desert dust may contribute to the migration of prokaryotic microbes on a global scale (trans-oceanic, trans-continental), thus being an important source of microbial diversity in the earth's ecosystem and may explain the global distribution of some microbial organisms throughout the worlds' ocean. We hypothesize that such organisms may be those that are more abundant in aerosol and have a higher survival rate during transport. A more detailed comparison between airborne microbial diversity/viability and microbes that are cosmopolitan in water bodies will substantiate (or refute) this hypothesis. 

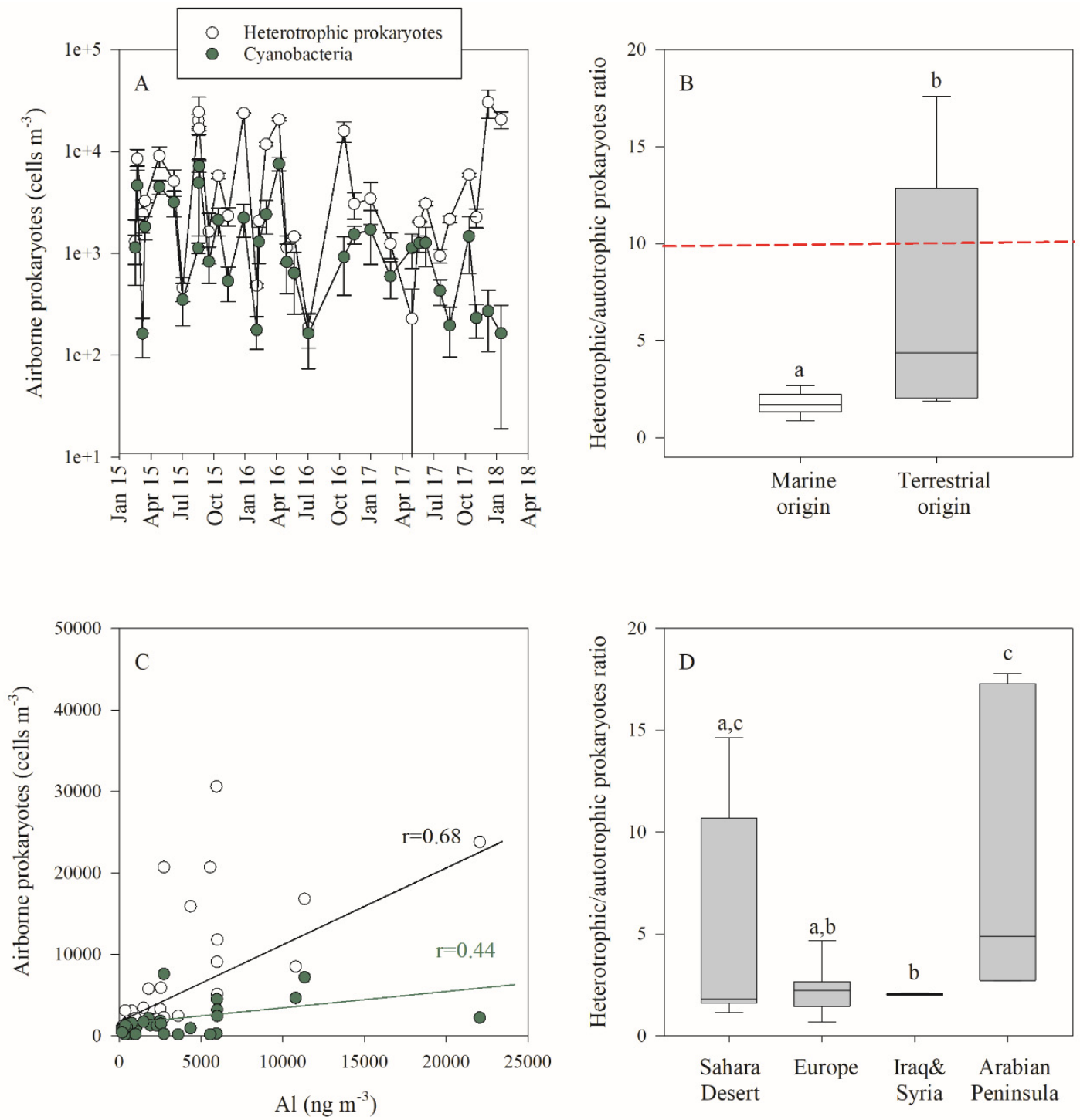

Figure 3. (A) Temporal variability of dust-associated airborne heterotrophic (white) and autotrophic (green) bacteria between 2015-2018 at the SE Mediterranean coast. Values presented are the averages and corresponding standard deviation in each time point $(n=3)$. (B) The relationship between autotrophic and heterotrophic airborne prokaryotes based on air-mass back trajectories. The dashed red line signifies the "typical" heterotrophic to autotrophic prokaryotic ratio in the SE Mediterranean seawater. (C) The relationship between $\mathrm{Al}$ concentration and airborne heterotrophic (white) and autotrophic (green) bacteria (Pearson linear regression, $p<0.05$ ). (D) The relationship between autotrophic and heterotrophic airborne prokaryotes based on the main backward trajectory prior dust/aerosols collection. The horizontal line within the box represents the median value. The letters above the box-plots represent significant differences (ANOVA, $p<0.05$ ) for mean values between sampling sites.

The averaged ratio between heterotrophic and autotrophic prokaryotes in marine-origin trajectory events was $\sim 1.7 \pm 0.6$ (median $=1.7$ ), regardless of the date of sampling and the overall airborne cell concentration (Figure 3B). On the contrary, the averaged ratio between heterotrophic and autotrophic prokaryotes when terrestrial-origin events occurred was significantly larger $(6.8 \pm 6.1)$ and more variable $(\sim 1-18$, median $=4.4$, $t$-test, $p=0.02)$ (Figure 3B). Airborne cyanobacteria (and other eukaryotic algae) originate primarily from seawater (e.g., aerosolized by waves action and sea-foam) and to a lesser extent from soil surfaces, tree barks, rocks etc. [43]. Thus, it is not surprising that marine-originating trajectories carried relatively more cyanobacteria than terrestrial, resulting in the observed different heterotrophic to autotrophic prokaryotes ratio (Figure 3B). Further, the heterotrophic/cyanobacterial 
ratio in dust/aerosol samples arriving from the Southeast (Saudi Arabia, terrestrial origin) was higher than in events originating from other terrestrial trajectories that were closer to the Mediterranean Sea (Figure 3D). This is consistent with the notion that most of the airborne cyanobacteria in our samples had a marine origin.

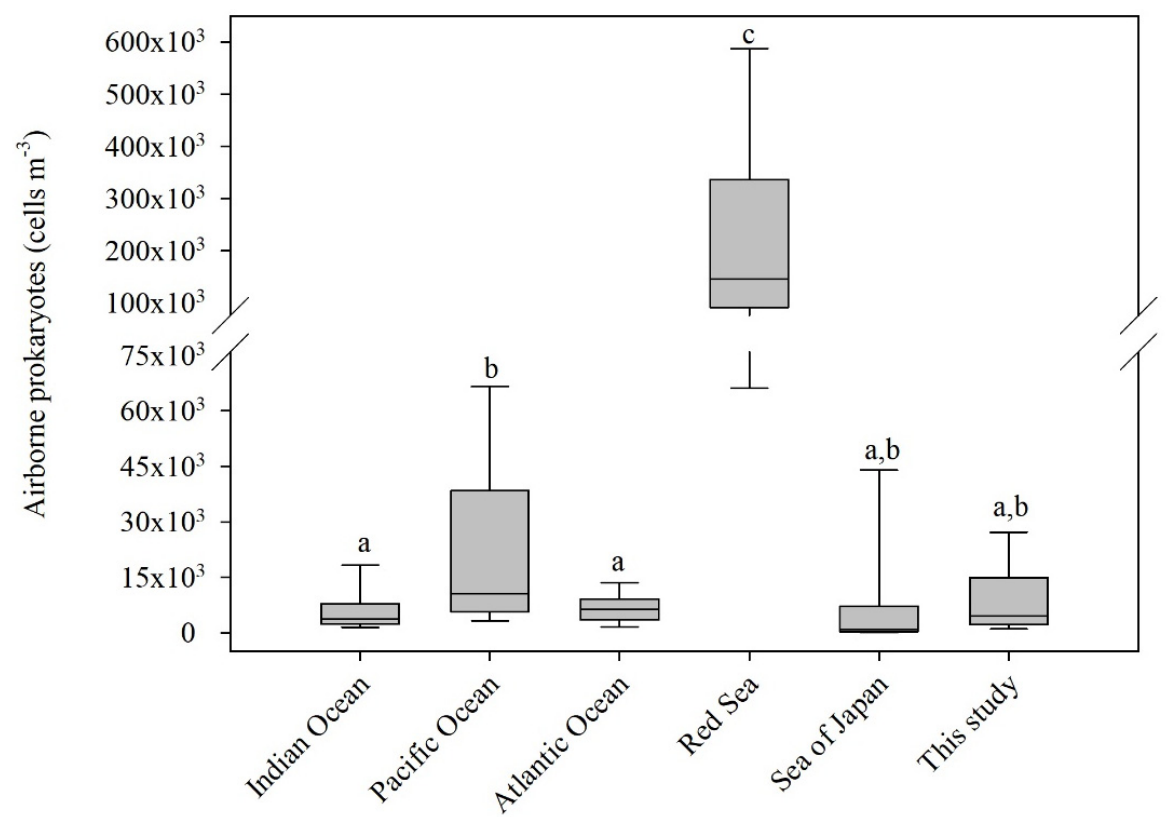

Figure 4. Compilation of airborne prokaryotes abundance over the oceans. Data was compiled from References [12,32-34] and this study. Box-Whisker plots show the interquartile range (25th-75th percentile) of the data set. The horizontal line within the box represents the median value. The letters above the box-plots represent significant differences (ANOVA, $p<0.05$ ) for mean values between sampling sites.

Interestingly, while the ratio between heterotrophic microbes and cyanobacteria at the surface SE Mediterranean Sea is usually 10:1 [44-46], airborne ratios were usually lower (median $<5: 1$, both for marine and terrestrial origins, Figure 3B). This difference may suggest that cyanobacteria are more efficiently aerosolized and/or that they better survive during transport in the air than heterotrophic microorganisms. It is possible that this is because cyanobacteria tend to be free living in seawater while heterotrophic bacteria are preferentially associated with larger marine particles and aggregates [47-49]. Moreover, many algal and cyanobacteria species have dormant life-stages which enable them to survive harsh conditions such as those found in the atmosphere [50,51]. Indeed, it has already been shown in the early 1960s that wind can transfer algal cysts which can become viable once deposited in sterile water [52]. It is to be noted, though, that some heterotrophic bacteria can also form spores or have the genetic machinery to tolerate the harsh atmospheric conditions. For example, Firmicutes sp., which are often found in dust samples [4,9,53], can form spores to facilitate atmospheric survival [33]. Thus, the viability and survival of airborne microorganisms (both autotrophic and heterotrophic) faced with the multi stressors often found in the atmosphere depends on their genetic capabilities to regulate protective proteins [54], their abundance in the source particles [17,55], their association with aerosol particle surfaces during transport, the aerosol's size spectrum, as well as climatic and meteorological conditions that determine the humidity and UV exposure during transport $[17,42]$.

The anthropogenic fraction in aerosols is enriched in dust after passing over populated and industrialized urban areas such as Europe [3,56]. Previous studies in the East Mediterranean demonstrated that the anthropogenic components in aerosols are enriched in trace metals (e.g., $\mathrm{Cd}$, $\mathrm{Pb}, \mathrm{Zn}, \mathrm{Cu}$ ) relative to $\mathrm{Al}[57,58]$, as well as in nitrogen and phosphorus compounds derived from combustion and/or agricultural sources $[3,59,60]$. Once these trace metals are deposited in seawater 
they can either relieve nutrients limitation for phytoplankton/bacteria in the surface water [61-63], or cause the opposite response by toxifying specific microbial populations [64,65]. Here, we found a reverse exponential relationship between $\mathrm{Pb} / \mathrm{Al}$ or $\mathrm{Cu} / \mathrm{Al}$ (as indicators for anthropogenic fraction and other metals toxicity) and the number of airborne prokaryotes in our samples (Figure 5). While it is unlikely that airborne microbes are active during atmospheric transport, previous studies demonstrated that once deposited in sea/lake water some of them become viable $[7,9,10,30]$. We postulate that viable airborne microorganisms attached to aerosol particles with relatively high anthropogenic fraction (e.g., $\mathrm{Pb} / \mathrm{Al}$ or $\mathrm{Cu} / \mathrm{Al}$ ) may be more likely to experience toxic levels of trace metals upon transport and deposition - even more than the ambient microbial populations (i.e., [64,65]), as many of them are attached to the aerosol particles. Thus, assuming dust events will become more frequent in the future [24], increasing the removal of anthropogenic aerosols during transport, airborne microbes may become less viable upon deposition in water bodies. Alternatively, this association may provide ecological survival advantages to specific microbial populations who are less susceptible to trace metals toxicity, thus impacting microbial diversity. Therefore, trace metals such as $\mathrm{Pb}$ and $\mathrm{Cu}$ may act as important selective agents for the successful dispersal and establishment of airborne microbes in sea/lake water.
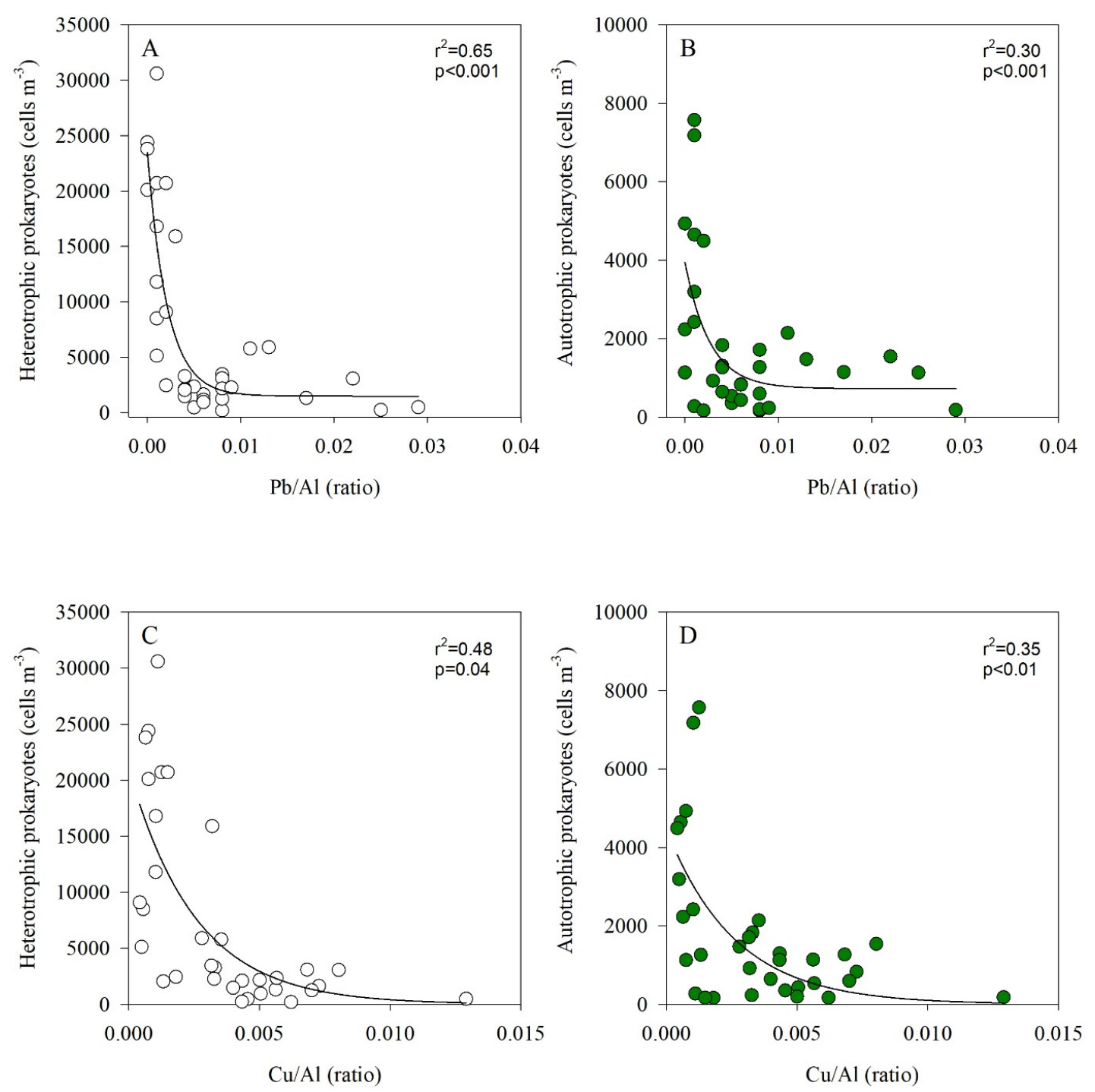

Figure 5. The relationship between the $\mathrm{Pb} / \mathrm{Al}(\mathbf{A}, \mathbf{B})$ and $\mathrm{Cu} / \mathrm{Al}(\mathbf{C}, \mathbf{D})$ ratios and heterotrophic prokaryotes $(\mathbf{A}, \mathbf{C})$ and autotrophic prokaryotes $(\mathbf{B}, \mathbf{D})$ abundance. 


\section{Conclusions}

We show that airborne microbes are common over the SE Mediterranean Sea throughout the year and that their abundance in air is mostly affected by their source and atmospheric route prior to deposition, as well as the concentration of dust/aerosols in the air. Yet, the mechanisms involved in the dispersal, activity, and diversity of airborne microorganisms remain to be studied. Such efforts should include standardization in collection protocols (i.e., instrumentation) and consistent methods for quantifying airborne microbes' abundances and diversity (i.e., microscopy, qPCR, different culturing techniques). Applying metagenomics approaches as well as evaluating the mechanisms that allow for their survival during transport and after deposition would increase our understanding of the biodiversity of microbes in the air and after deposition on land and in the ocean with their dispersal and relevance to biogeography. Given the pivotal role of airborne microbes, especially in marine areas close to deserts, we stress that future models should consider the contribution of the biological component in aerosols/dust to marine biogeochemistry.

Author Contributions: Conceptualization, E.R., A.P. and B.H.; formal analysis, E.R. and N.B.; funding acquisition, E.R., A.P. and B.H.; investigation, E.R., N.B. and B.H.; methodology, A.P.; project administration, E.R.; resources, E.R.

Funding: This research was funded by the Israel Science Foundation grant number 1211/17 (E.R. and B.H.) and by the NSF-OCE grant number 0850467 (A.P.). The authors also acknowledge the Mermex-TRANCOMED grant (B.H. and E.R.) of the French ENVIMED program.

Acknowledgments: We are grateful to Dar Golomb for contrasting the schematic illustration presented in Figure 1.

Conflicts of Interest: The authors declare that the research was conducted in the absence of any potential conflict of interest.

\section{References}

1. Mackey, K.R.M.; Buck, K.N.; Casey, J.R.; Cid, A.; Lomas, M.W.; Sohrin, Y.; Paytan, A. Phytoplankton responses to atmospheric metal deposition in the coastal and open-ocean Sargasso Sea. Front. Microbiol. 2012, 3, 1-15. [CrossRef] [PubMed]

2. Guieu, C.; Aumont, O.; Paytan, A.; Bopp, L.; Law, C.S.; Mahowald, N.; Achterberg, E.P.; Marañón, E.; Salihoglu, B.; Crise, A.; et al. Global biogeochemical cycles deposition to Low Nutrient Low Chlorophyll regions. Global Biogeochem. Cycles 2014, 28, 1179-1198. [CrossRef]

3. Herut, B.; Rahav, E.; Tsagaraki, T.M.; Giannakourou, A.; Tsiola, A.; Psarra, S.; Lagaria, A.; Papageorgiou, N.; Mihalopoulos, N.; Theodosi, C.N.; et al. The potential impact of Saharan dust and polluted aerosols on microbial populations in the east Mediterranean Sea, an overview of a mesocosm experimental approach. Front. Mar. Sci. 2016, 3, 226. [CrossRef]

4. Gat, D.; Mazar, Y.; Cytryn, E.; Rudich, Y. Origin-dependent variations in the atmospheric microbiome community in Eastern Mediterranean dust storms. Environ. Sci. Technol. 2017, 51, 6709-6718. [CrossRef]

5. Maki, T.; Kurosaki, Y.; Onishi, K.; Lee, K.C.; Pointing, S.B.; Jugder, D.; Yamanaka, N.; Hasegawa, H.; Shinoda, M. Variations in the structure of airborne bacterial communities in Tsogt-Ovoo of Gobi desert area during dust events. Air Qual. Atmos. Heal. 2017, 10, 249-260. [CrossRef]

6. Behzad, H.; Mineta, K.; Gojobori, T. Global ramifications of dust and sandstorm microbiota. Genome Biol. Evol. 2018, 10, 1970-1987. [CrossRef] [PubMed]

7. Reche, I.; Ortega-Retuerta, E.; Romera, O.; Pulido-Villena, E.; Morales-Baquero, R.; Casamayor, E.O. Effect of Saharan dust inputs on bacterial activity and community composition in Mediterranean lakes and reservoirs. Limnol. Oceanogr. 2009, 54, 869-879. [CrossRef]

8. Sharoni, S.; Trainic, M.; Schatz, D.; Lehahn, Y.; Flores, M.J.; Bidle, K.D.; Ben-Dor, S.; Rudich, Y.; Koren, I.; Vardi, A. Infection of phytoplankton by aerosolized marine viruses. Proc. Natl. Acad. Sci. USA 2015, 112, 6643-6647. [CrossRef]

9. Rahav, E.; Ovadia, G.; Paytan, A.; Herut, B. Contribution of airborne microbes to bacterial production and $\mathrm{N}_{2}$ fixation in seawater upon aerosol deposition. Geophys. Res. Lett. 2016, 43. [CrossRef] 
10. Rahav, E.; Paytan, A.; Mescioglu, E.; Galletti, Y.; Rosenfeld, S.; Raveh, O.; Santinelli, C.; Ho, T.; Herut, B. Airborne microbes contribute to $\mathrm{N}_{2}$ fixation in surface water of the Northern Red Sea. Geophys. Res. Lett. 2018, 2-10. [CrossRef]

11. Christner, B.C.; Morris, C.E.; Foreman, C.M.; Cai, R.; David, C. Ubiquity of biological ice nucleators in snowfall. Sceine 2008, 5867, 1214. [CrossRef]

12. Mayol, E.; Arrieta, J.M.; Jiménez, M.A.; Martínez-Asensio, A.; Garcias-Bonet, N.; Dachs, J.; González-Gaya, B.; Royer, S.J.; Benítez-Barrios, V.M.; Fraile-Nuez, E.; Duarte, C.M. Long-range transport of airborne microbes over the global tropical and subtropical ocean. Nat. Commun. 2017, 8, 1-8. [CrossRef]

13. Polymenakou, P.N. Atmosphere: A source of pathogenic or beneficial microbes? Atmosphere (Basel) 2012, 3, 87-102. [CrossRef]

14. Katra, I.; Arotsker, L.; Krasnov, H.; Zaritsky, A.; Kushmaro, A.; Ben-Dov, E. Richness and diversity in dust stormborne biomes at the southeast mediterranean. Sci. Rep. 2014, 4, 5265. [CrossRef]

15. Mohr, A. Fate and transport of microorganisms in air. In Manual of Environmental Microbiology; Hurst, C., Crawford Garland, J., Lipson, D., Mills, A., Stetzenbach, L., Eds.; ASM Press: Washington, DC, USA, 2007; pp. 961-971.

16. Womack, A.M.; Bohannan, B.J.M.; Green, J.L. Biodiversity and biogeography of the atmosphere. Philos. Trans. R. Soc. Lond. B Biol. Sci. 2010, 365, 3645-3653. [CrossRef]

17. Griffin, D.W. Atmospheric movement of microorganisms in clouds of desert dust and implications for human health. Clin. Microbiol. Rev. 2007, 20, 459-477. [CrossRef] [PubMed]

18. Rahav, E.; Paytan, A.; Chien, C.-T.; Ovadia, G.; Katz, T.; Herut, B. The impact of atmospheric dry deposition associated microbes on the southeastern Mediterranean Sea surface water following an intense dust storm. Front. Mar. Sci. 2016, 3. [CrossRef]

19. Draxler, R.R.; Rolph, G.D. Evaluation of the transfer coefficient matrix (TCM) approach to model the atmospheric radionuclide air concentrations from Fukushima. J. Geophys. Res. Atmos. 2012, 117, 1-10. [CrossRef]

20. Herut, B.; Nimmo, M.; Medway, A.; Chester, R.; Krom, M.D. Dry atmospheric inputs of trace metals at the Mediterranean coast of Israel (SE Mediterranean): Sources and fluxes. Atmos. Environ. 2001, 35, 803-813. [CrossRef]

21. Koçak, M.; Kubilay, N.; Herut, B.; Nimmo, M. Dry atmospheric fluxes of trace metals (Al, Fe, Mn, Pb, Cd, Zn, $\mathrm{Cu}$ ) over the Levantine Basin: A refined assessment. Atmos. Environ. 2005, 39, 7330-7341. [CrossRef]

22. Rahav, E.; Raveh, O.; Hazan, O.; Gordon, N.; Kress, N.; Silverman, J.; Herut, B. Impact of nutrient enrichment on productivity of coastal water along the SE Mediterranean shore of Israel-A bioassay approach. Mar. Pollut. Bull. 2018, 127, 559-567. [CrossRef]

23. Raveh, O.; David, N.; Rilov, G.; Rahav, E. The temporal dynamics of coastal phytoplankton and bacterioplankton in the Eastern Mediterranean Sea. PLoS ONE 2015, 10, 1-23. [CrossRef] [PubMed]

24. Lawrence, C.R.; Neff, J.C. The contemporary physical and chemical flux of aeolian dust: A synthesis of direct measurements of dust deposition. Chem. Geol. 2009, 267, 46-63. [CrossRef]

25. Kellogg, C.A.; Griffin, D.W. Aerobiology and the global transport of desert dust. Trends Ecol. Evol. 2006, 21, 638-644. [CrossRef] [PubMed]

26. Seifried, J.S.; Wichels, A.; Gerdts, G. Spatial distribution of marine airborne bacterial communities. Microbiol. Open 2015, 25, 475-490. [CrossRef]

27. Rahav, E.; Shun-Yan, C.; Cui, G.; Liu, H.; Tsagaraki, T.M.; Giannakourou, A.; Tsiola, A.; Psarra, S.; Lagaria, A.; Mulholland, M.R.; et al. Evaluating the impact of atmospheric depositions on springtime dinitrogen fixation in the Cretan Sea (Eastern Mediterranean)_A mesocosm approach. Front. Mar. Sci. 2016, 3, 1-13. [CrossRef]

28. Tsagaraki, T.M.; Herut, B.; Rahav, E.; Berman Frank, I.R.; Tsiola, A.; Tsapakis, M.; Giannakourou, A.; Gogou, A.; Panagiotopoulos, C.; Violaki, K.; et al. Atmospheric deposition effects on plankton communities in the Eastern Mediterranean: A mesocosm experimental approach. Front. Mar. Sci. 2017, 4, 210. [CrossRef]

29. Krom, M.D.; Shi, Z.; Stockdale, A.; Berman-Frank, I.; Giannakourou, A.; Herut, B.; Lagaria, A.; Papageorgiou, N.; Pitta, P.; Psarra, S.; et al. Response of the Eastern Mediterranean microbial ecosystem to dust and dust affected by acid processing in the atmosphere. Front. Mar. Sci. 2016, 3. [CrossRef]

30. Peter, H.; Hörtnagl, P.; Reche, I.; Sommaruga, R. Bacterial diversity and composition during rain events with and without Saharan dust influence reaching a high mountain lake in the Alps. Environ. Microbiol. Rep. 2014, 6, 618-624. [CrossRef] 
31. Reche, I.; D'Orta, G.; Mladenov, N.; Winget, D.M.; Suttle, C.A. Deposition rates of viruses and bacteria above the atmospheric boundary layer. ISME J. 2018, 12, 1154-1162. [CrossRef] [PubMed]

32. Mayol, E.; Jiménez, M.A.; Herndl, G.J.; Duarte, C.M.; Arrieta, J.M. Resolving the abundance and air-sea fluxes of airborne microorganisms in the North Atlantic Ocean. Front. Microbiol. 2014, 5, 1-9. [CrossRef] [PubMed]

33. Yamaguchi, N.; Park, J.; Kodama, M.; Ichijo, T.; Baba, T.; Nasu, M. Changes in the airborne bacterial community in outdoor environments following Asian dust events. Microbes Environ. 2014, 29, 82-88. [CrossRef] [PubMed]

34. Yahya, R.Z.; Duarte, C.M.; Cusack, M.; Arrieta, J.M. Airborne prokaryote and virus abundance over the Red Sea. Front. Microbiol. 2019. [CrossRef]

35. Lighthart, B.; Shaffer, B.T. Survey of culturable airborne bacteria at four diverse locations in Oregon: Urban, rural, forest, and coastal. Microb. Ecol. 1997, 34, 167-177.

36. Gandolfi, I.; Bertolini, V.; Bestetti, G.; Ambrosini, R.; Innocente, E.; Rampazzo, G.; Papacchini, M.; Franzetti, A. Spatio-temporal variability of airborne bacterial communities and their correlation with particulate matter chemical composition across two urban areas. Appl. Microbiol. Biotechnol. 2015, 99, 4867-4877. [CrossRef]

37. Bowers, R.M.; McLetchie, S.; Knight, R.; Fierer, N. Spatial variability in airborne bacterial communities across land-use types and their relationship to the bacterial communities of potential source environments. ISME J. 2011, 5, 601-612. [CrossRef]

38. Tormo, R.; Recio, D.; Silva, I.; MUÑOZ, A. Pollen traps in south-west Spain. Eur. J. Phycol. 2011, 36, 385-390. [CrossRef]

39. Genitsaris, S.; Kormas, K.A.; Moustaka-Gouni, M. Airborne algae and cyanobacteria: Occurrence and related health effects. Front. Biosci. (Elite Ed.) 2011, 3, 772-787.

40. Jones, A.M.; Harrison, R.M. The effects of meteorological factors on atmospheric bioaerosol concentrations-A review. Sci. Total Environ. 2004, 326, 151-180. [CrossRef]

41. Bowers, R.M.; Clements, N.; Emerson, J.B.; Wiedinmyer, C.; Hannigan, M.P.; Fierer, N. Seasonal variability in bacterial and fungal diversity of the near-surface atmosphere. Environ. Sci. Technol. 2013, 47, 12097-12106. [CrossRef]

42. Roy-Ocotla, G.; Carrera, J. Aeroalgae: Responses to some aerobiological questions. Grana 1993, 32, 48-56. [CrossRef]

43. Sahu, N.; Tangutur, A.D. Airborne algae: Overview of the current status and its implications on the environment. Aerobiologia (Bologna) 2015, 31, 89-97. [CrossRef]

44. Hazan, O.; Silverman, J.; Sisma-Ventura, G.; Ozer, T.; Gertman, I.; Shoham-Frider, E.; Kress, N.; Rahav, E. Mesopelagic prokaryotes alter surface phytoplankton production during simulated deep mixing experiments in Eastern Mediterranean Sea waters. Front. Mar. Sci. 2018, 5. [CrossRef]

45. Rahav, E.; Silverman, J.; Raveh, O.; Hazan, O.; Rubin-Blum, M.; Zeri, C.; Gogou, A.; Kralj, M.; Pavlidou, A.; Kress, N. The deep water of Eastern Mediterranean Sea is a hotspot for bacterial activity. Deep Sea Res. Part II Top. Stud. Oceanogr. 2019. [CrossRef]

46. Livanou, E.; Lagaria, A.; Santi, I.; Pavlidou, A.; Lika, K.; Psarra, S. Pigmented and Heterotrophic Nanoflagellates: Abundance and grazing on picoplankton in the ultra-oligotrophic Eastern Mediterranean Sea. Deep. Res. Part II 2019. [CrossRef]

47. Passow, U. Production of transparent exopolymer particles (TEP) by phyto- and bacterioplankton. Mar. Ecol. Prog. Ser. 2002, 236, 1-12. [CrossRef]

48. Bar-Zeev, E.; Berman, T.; Rahav, E.; Dishon, G.; Herut, B.; Kress, N.; Berman-Fran, I. Transparent exopolymer particle (TEP) dynamics in the eastern Mediterranean Sea. Mar. Ecol. Prog. Ser. 2011, 431. [CrossRef]

49. Bar-Zeev, E.; Passow, U.; Romero-Vargas Castrillón, S.; Elimelech, M. Transparent exopolymer particles: From aquatic environments and engineered systems to membrane biofouling. Environ. Sci. Technol. 2015, 49, 691-707. [CrossRef] [PubMed]

50. Kristiansen, J. Dispersal of freshwater algae-A review. Hydrobiologia 1996, 336, 151-157. [CrossRef]

51. Hamilton, W.D.; Lenton, T.M. Spora and gaia: How microbes fly with their clouds. Ethol. Ecol. Evol. 1998, 10, 1-16. [CrossRef]

52. Maguire, B. The passive dispersal of small aquatic organisms and their colonization of isolated bodies of water. Ecol. Modell. 1963, 33, 161-185. [CrossRef] 
53. Yamaguchi, N.; Ichijo, T.; Sakotani, A.; Baba, T.; Nasu, M. Global dispersion of bacterial cells on Asian dust. Sci. Rep. 2012, 2, 1-6. [CrossRef]

54. Kulkarni, G.; Wu, C.H.; Newmana, D.K. The general stress response factor EcfG regulates expression of the C-2 hopanoid methylase HpnP in Rhodopseudomonas palustris TIE-1. J. Bacteriol. 2013, 195, 2490-2498. [CrossRef] [PubMed]

55. Pedrós-Alió, C. Marine microbial diversity: Can it be determined? Trends Microbiol. 2006, 14, $257-263$. [CrossRef] [PubMed]

56. Koçak, M.; Theodosi, C.; Zarmpas, P.; Suguret, M.J.M.; Herut, B.; Kallos, G.; Mihalopoulos, N.; Kubilay, N.; Nimmo, M. Influence of mineral dust transport on the chemical composition and physical properties of the Eastern Mediterranean aerosol. Atmos. Environ. 2012, 57, 266-277. [CrossRef]

57. Herut, B.; Collier, R.; Krom, M.D. The role of dust in supplying nitrogen and phosphorus to the southeast Mediterranean. Limnol. Oceanogr. 2002, 47, 870-878. [CrossRef]

58. Koçak, M.; Kubilay, N.; Tuğrul, S.; Mihalopoulos, N. Atmospheric nutrient inputs to the northern levantine basin from a long-term observation: Sources and comparison with riverine inputs. Biogeosciences 2010, 7, 4037-4050. [CrossRef]

59. Herut, B.; Krom, M.D.D.; Pan, G.; Mortimer, R. Atmospheric input of nitrogen and phosphorus to the Southeast Mediterranean: Sources, fluxes, and possible impact. Limnol. Ocean. 1999, 44, 1683-1692. [CrossRef]

60. Duce, R.A.; LaRoche, J.; Altieri, K.; Arrigo, K.R.; Baker, A.R.; Capone, D.G.; Cornell, S.; Dentener, F.; Galloway, J.; Ganeshram, R.S.; et al. Impacts of atmospheric anthropogenic nitrogen on the open ocean. Science 2008, 320, 893-897. [CrossRef]

61. Mills, M.M.; Ridame, C.; Davey, M.; La Roche, J.; Geider, R.J. Iron and phosphorus co-limit nitrogen fixation in the eastern tropical North Atlantic. Nature 2004, 429, 292-294. [CrossRef]

62. Guo, C.; Xia, X.; Pitta, P.; Herut, B.; Rahav, E.; Berman-Frank, I.; Giannakourou, A.; Tsiola, A.; Tsagaraki, T.M.; Liu, H. Shifts in microbial community structure and activity in the ultra-oligotrophic Eastern Mediterranean Sea driven by the deposition of Saharan Dust and European Aerosols. Front. Mar. Sci. 2016, 3, 1-13. [CrossRef]

63. Mackey, K.R.M.; Rivlin, T.; Grossman, A.R.; Post, A.F.; Paytan, A. Picophytoplankton responses to changing nutrient and light regimes during a bloom. Mar. Biol. 2009, 156, 1531-1546. [CrossRef]

64. Paytan, A.; Mackey, K.R.M.; Chen, Y.; Lima, I.D.; Doney, S.C.; Mahowald, N.; Labiosa, R.; Post, A.F.A.F. Toxicity of atmospheric aerosols on marine phytoplankton. Proc. Natl. Acad. Sci. USA 2009, 106, 4601-4605. [CrossRef]

65. Jordi, A.; Basterretxea, G.; Tovar-Sánchez, A.; Alastuey, A.; Querol, X. Copper aerosols inhibit phytoplankton growth in the Mediterranean Sea. Proc. Natl. Acad. Sci. USA 2012, 109, 21246-21249. [CrossRef] [PubMed] 